\title{
Paper tests for occult blood in faeces and some observations on the fate of swallowed red cells
}

\author{
R. G. HUNTSMAN AND J. LIDDELL \\ From the Department of Clinical Pathology, Guy's Hospital, London
}

SYNOPSIS Paper tests for occult blood were assessed on faecal specimens from adults. An orthotolidine/sodium perborate and a modified orthotolidine/peroxide test were found to be reasonably satisfactory. The Hematest and Occultest tablets and a paper guaiac test were unsatisfactory.

A large number of false positive results was obtained in children and infants. It is suggested that this might be due to meat derivatives reaching the faeces more easily in the young.

Red cells labelled with either $\mathrm{Cr}^{51}$ or $\mathrm{Fe}^{59}$ were swallowed by human volunteers. Although between $45 \%$ and $73 \%$ of the red cell iron reappeared in the faeces, the peroxidase activity of the labelled material dropped six-fold on passage through the alimentary canal.

The multiplicity of techniques for detecting occult blood in faeces suggests that none is entirely satisfactory, but the hitherto widespread use of the benzidine tube test implies that that is the method which best meets practical requirements. However, the manufacture of benzidine has been associated with the development of cancer in industrial workers (Baker, 1953) and as a result benzidine has recently become difficult to obtain. Of the possible alternative tests, the orthotolidine and guaiac paper techniques are simple and inexpensive, with the result that they are being increasingly used in wards and general practice, and in the laboratory the use of such methods eliminates much of the distasteful work, especially the cleaning of glassware. We have, therefore, carried out a series of tests designed to assess the reliability of some of the paper techniques and have compared them with tube benzidine tests. The sensitivity measurements have been based on the amount of altered orally administered blood in the stools as determined by the use of $\mathrm{Cr}^{51}$ labelled red cells rather than on artificial mixtures of fresh blood and faeces.

\section{METHODS}

TUBE TESTS FOR OCCULT BLOOD The benzidine tube test was performed on boiled faecal suspensions using varying dilutions of benzidine as described by Varley (1958).

PAPER TESTS FOR OCCULT BLOOD We performed four paper tests for comparison.

Received for publication 7 November 1960.
Hematest and Occultest Both were performed and interpreted according to the manufacturers' ${ }^{1}$ instructions for the Hematest tablet.

Paper orthotolidine and sodium perborate test With the 'perborate test' of Abbott (personal communication) a very thin smear of faeces the size of a postage stamp was made in the centre of a Whatman No. 1 filter paper. About six large drops of a freshly prepared mixture of equal volumes of $2 \%$ sodium perborate in water and $2 \%$ orthotolidine in glacial acetic acid were added to the centre of the smear. A blue colour forming within two minutes outside the area of the faecal smear was regarded as positive. We found that the stock solutions could be kept at room temperature for about a week, after which the sodium perborate began to deteriorate.

Paper orthotolidine test This was performed as described by Moss (1955). Two modifications were made. First, the results were read after 30 seconds as many normal specimens gave a positive result after a longer time. Secondly, $2 \%, 1 \%$, and $0.4 \%$ orthotolidine solutions were used as well as the $4 \%$ in an attempt to reduce the sensitivity of the test.

Paper guaiac test This was performed as described by Morgan and Roantree (1957).

NEGATIVE CONTROLS There were (1) normal adults on a normal diet excluding aspirin; (2) normal adults on a diet excluding meat and offal and taking no drugs. Collections were controlled by the use of carmine markers. Two of the volunteers in this group were shown to be free of significant gastrointestinal bleeding by estimating the radioactivity of their faeces after intravenous injection of $\mathrm{Cr}^{51}$-labelled red cells. (3) Normal children on a normal diet; (4) normal children on a meat- and offal-free diet.

${ }^{1}$ Ames Company Limited. 
These had previously given positive benzidine tube tests on a normal diet. (5) Normal bottle-fed babies aged from a $\frac{1}{2}$ to 5 months. This group was chosen to reduce errors due to bleeding maternal nipples, haemorrhagic disease of the newborn, and teething. The results from babies over 3 months of age have been placed in a separate category, since mixed feeding usually began at about this time.

POSITIVE CONTROLS Two normal adults who were on a meat- and offal-free diet and taking no drugs, swallowed known amounts of their own red cells, which had been labelled with a radioactive isotope $\mathrm{Cr}^{51}$ (Veall and Vetter, 1958). The red cells, suspended in milk, were drunk over a 12-hour period in order to simulate high gastrointestinal bleeding. The faeces were collected, weighed, and their radioactivity measured in a ring of six GeigerMuller counters. This was compared with the radioactivity of a sample of the swallowed blood. The data so obtained were used to derive a figure for the concentration of blood giving rise to red cell residues in the faecal specimens.

In order to measure the absorption of iron after swallowing blood, red cells labelled with $\mathrm{Fe}^{59}$ were drunk, and the experiment continued as with the $\mathrm{Cr}^{51}$-labelled blood. The red cells were labelled in vivo by the intravenous injection of $\mathrm{Fe}^{59}$ into a rabbit and venesection 10 days later, by which time some of the $\mathrm{Fe}^{59}$ had been incorporated in the haem radicle. The resulting rabbit red cells were washed with normal saline and mixed with the subjects' own blood to give the required volume.

One child (a negro hydrocephalic) continued to give strongly positive occult blood tests while on a diet. The child was excluded from the series as there was a history of anaemia, treated with intramuscular iron, and gastrointestinal bleeding was suspected. One baby (aged 2 weeks) was excluded from Table III because the health visitor noticed that it was passing black stools. The tests for occult blood were strongly positive.

\section{RESULTS}

NEGATIVE CONTROLS Tables I, II, and III show the results obtained.

POSITIVE CONTROLS The results obtained on two subjects on a meat-free diet are shown in Table IV. These subjects had swallowed amounts of $\mathrm{Cr}^{51}$. labelled blood varying between 5 and $20 \mathrm{ml}$. The

TABLE I

RESULTS ON NORMAL ADULTS

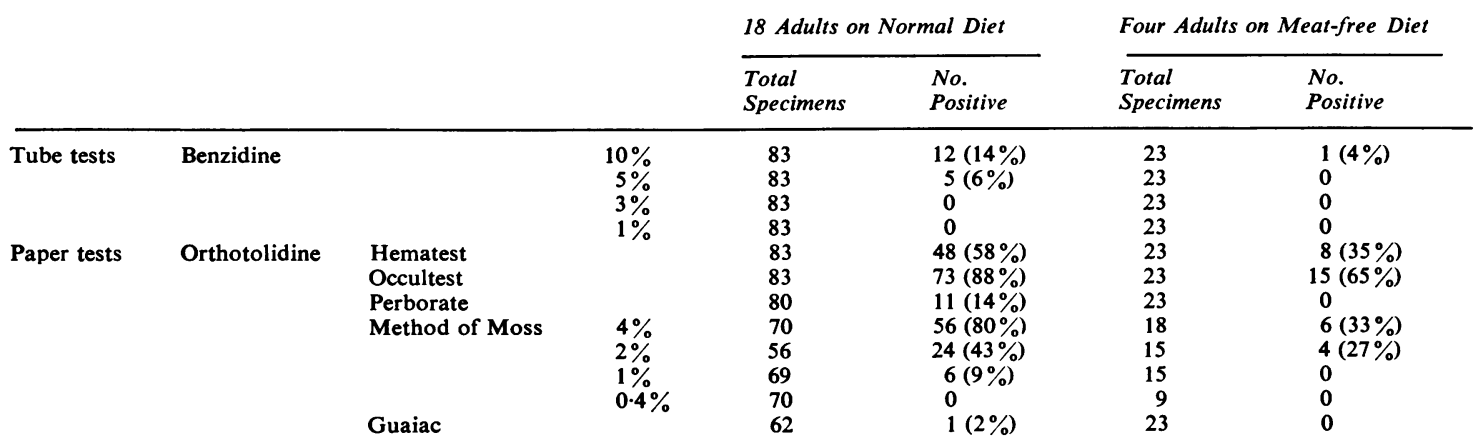

TABLE II

RESULTS ON NORMAL CHILDREN

\begin{tabular}{|c|c|c|c|c|c|}
\hline & & & & $\begin{array}{l}117 \text { Specimens from } 86 \text { Children } \\
\text { on Normal Diet } \\
\text { No. Positive }\end{array}$ & $\begin{array}{l}18 \text { Specimens from Three Children } \\
\text { on Meat-free Diet } \\
\text { No. Positive }\end{array}$ \\
\hline Paper tests & Orthotolidine & $\begin{array}{l}\text { Hematest } \\
\text { Occultest } \\
\text { Perborate } \\
\text { Method of Moss } \\
\text { Guaiac }\end{array}$ & $\begin{array}{l}10 \% \\
5 \% \\
3 \% \\
1 \%\end{array}$ & $\begin{array}{c}49(42 \%) \\
36(31 \%) \\
24(21 \%) \\
3(2.5 \%) \\
94(80 \%) \\
115(98 \%) \\
46(39 \%) \\
106(91 \%) \\
86(74 \%) \\
63(54 \%) \\
25(21 \%) \\
3(2.5 \%)\end{array}$ & $\begin{array}{l}1(5 \cdot 5 \%) \\
0 \\
0 \\
0 \\
1(5 \cdot 5 \%) \\
10(55 \%) \\
1(5 \cdot 5 \%) \\
8(45 \%) \\
2(11 \%) \\
0 \\
0 \\
0\end{array}$ \\
\hline
\end{tabular}


TABLE III

RESULTS ON NORMAL INFANTS

\begin{tabular}{|c|c|c|c|c|c|}
\hline & & & & $\begin{array}{l}32 \text { Specimens from } 32 \text { Babies } \\
\text { Aged } \frac{1}{2} \text { to } 3 \text { Months } \\
\text { No. Positive }\end{array}$ & $\begin{array}{l}28 \text { Specimens from } 28 \text { Babies } \\
\text { Aged } 3 \text { to } 5 \text { Months } \\
\text { No. Positive }\end{array}$ \\
\hline Tube tests & Benzidine & & $\begin{array}{l}10 \% \\
5 \% \\
3 \% \\
1 \%\end{array}$ & $\begin{array}{l}4(12 \%) \\
2(6 \%) \\
0 \\
0\end{array}$ & $\begin{array}{l}9(32 \%) \\
5(18 \%) \\
2(7 \%) \\
0\end{array}$ \\
\hline Paper tests & Orthotolidine & $\begin{array}{l}\text { Hematest } \\
\text { Occultest } \\
\text { Perborate } \\
\text { Method of Moss }\end{array}$ & $\begin{array}{l}4 \% \\
2 \% \\
1 \% \\
0.4 \%\end{array}$ & $\begin{array}{c}27(84 \%) \\
31(97 \%) \\
4(12 \%) \\
16(50 \%) \\
7(22 \%) \\
2(6 \%) \\
0 \\
1(3 \%)\end{array}$ & $\begin{array}{c}21(75 \%) \\
28(100 \%) \\
6(21 \%) \\
17(61 \%) \\
6(21 \%) \\
4(14 \%) \\
1(4 \%) \\
0\end{array}$ \\
\hline
\end{tabular}

concentrations of red cell residues were calculated from the $\mathrm{Cr}^{51}$ content of the faeces. It will be noted that below a critical concentration of red cell residues (about $3.2 \mathrm{ml}$. blood/100 g. faeces) the majority of the tests were negative. The main exceptions to this were those tests giving numerous false positive results with the negative controls, i.e., Hematest, Occultest, $4 \%$ and $2 \%$ Moss orthotolidine tests. The minimum amount of swallowed blood which gave the apparently critical concentration required for detection by the occult blood tests used was $10 \mathrm{ml}$. In every case the $\mathrm{Cr}^{51}$ label was excreted over a period of four days after ingestion, the maximum concentration occurring on the second day.

\section{DISCUSSION}

THE FATE OF SWALLOWED BLOOD In our experiments it was necessary to swallow $10 \mathrm{ml}$. of blood before it could be detected in the faeces. This was in agreement with some other authors, e.g., Needham and Simpson (1952) even though our results were not strictly comparable, since the blood was taken over a 12-hour period instead of in one dose.

Needham and Simpson found that when blood was emulsified directly with faeces, the Gregersen test could detect a concentration of $0.5 \mathrm{ml}$. blood in $100 \mathrm{~g}$. of faeces. We obtained a similar result with the tests employed by us. It is therefore of interest

TABLE IV

RESULTS OF OCCULT BLOOD TESTING ON FAECES OBTAINED AFTER SWALLOWING Cr $^{51}$-LABELLED BLOOD

\begin{tabular}{|c|c|c|c|c|c|c|c|c|c|c|c|c|}
\hline \multirow{3}{*}{$\begin{array}{l}\text { Concentration of } \\
\text { Red Cell Residues } \\
\text { Expressed as } \\
\text { ml. Blood/100 g. } \\
\text { Faeces }\end{array}$} & \multicolumn{4}{|c|}{ Tube Tests } & \multicolumn{8}{|c|}{ Paper Tests } \\
\hline & \multirow[t]{2}{*}{$\begin{array}{l}\text { Benzidine } \\
10 \%\end{array}$} & \multirow[t]{2}{*}{$5 \%$} & \multirow[t]{2}{*}{$3 \%$} & \multirow[t]{2}{*}{$1 \%$} & \multirow{2}{*}{\multicolumn{2}{|c|}{$\begin{array}{l}\text { Orthotolidine } \\
\text { Hematest Occultest }\end{array}$}} & \multirow[t]{2}{*}{ Perborate } & \multicolumn{4}{|c|}{ Method of Moss } & \multirow[t]{2}{*}{ Guaiac } \\
\hline & & & & & & & & $4 \%$ & $2 \%$ & $1 \%$ & $0.4 \%$ & \\
\hline 0.02 & - & - & - & - & - & + & - & + & - & - & - & - \\
\hline 0.02 & - & - & - & - & - & + & - & + & - & - & - & - \\
\hline 0.3 & - & - & - & - & - & + & - & + & + & - & - & - \\
\hline $0 \cdot 3$ & - & - & - & - & - & + & - & - & - & - & - & - \\
\hline 0.5 & - & - & - & - & + & + & - & - & - & - & - & - \\
\hline 0.7 & - & - & - & - & + & + & - & + & - & - & - & - \\
\hline 0.8 & - & - & - & - & - & + & - & + & - & - & - & - \\
\hline 0.9 & - & - & - & - & + & + & - & - & - & - & - & - \\
\hline $1 \cdot 2$ & - & - & - & - & + & + & - & + & - & - & - & - \\
\hline $1 \cdot 3$ & - & - & - & - & - & + & - & + & - & - & - & - \\
\hline 1.6 & - & - & - & - & + & + & - & + & + & - & - & - \\
\hline $1 \cdot 7$ & - & - & - & - & + & + & - & + & + & - & - & - \\
\hline $2 \cdot 1$ & - & - & - & - & + & + & + & + & + & - & - & - \\
\hline 2.4 & - & - & - & - & + & + & - & + & + & - & - & - \\
\hline 3.0 & - & - & - & - & - & + & - & + & + & - & - & - \\
\hline $3 \cdot 2$ & - & - & - & - & + & + & - & + & + & + & - & - \\
\hline 3.4 & + & + & + & - & + & + & + & + & + & + & + & + \\
\hline 3.8 & + & + & $\div$ & - & + & + & + & + & + & + & + & + \\
\hline $4 \cdot 2$ & + & + & + & + & + & + & + & + & + & + & + & + \\
\hline 5.6 & + & + & - & - & - & + & + & + & + & + & + & + \\
\hline 6.0 & + & + & + & + & + & + & + & + & + & + & + & + \\
\hline 8.2 & + & + & + & - & + & + & + & + & + & + & + & + \\
\hline
\end{tabular}


that when $\mathrm{Cr}^{51}$-labelled blood was swallowed and the concentration of blood products in the faeces was assessed by the $\mathrm{Cr}^{51}$ label, the tests could detect only about $3 \mathrm{ml}$. blood per $100 \mathrm{~g}$. faeces. This represents a six-fold drop in sensitivity.

If red cells are labelled with $\mathrm{Cr}^{51}$ the label becomes attached to the globin part of the haemoglobin (Gray and Sterling, 1950). When globin is digested in the alimentary tract, the $\mathrm{Cr}^{51}$ label would be set free and most of it is found in the faeces (Jones, 1958). In our experiments between $81 \%$ and $99 \%$ of the label was recovered. When the faecal blood concentration is calculated from the $\mathrm{Cr}^{51}$ content, the result will be too low because of the partial absorption of the label. The concentrations of red cell residues shown in Table IV are therefore a slight underestimate of the true figure.

The six-fold drop in peroxidase activity must be due to either or both of two factors, namely, (1) alteration of the haemoglobin molecule and (2) absorption of the iron-containing fraction.

In order to assess the part played by absorption of iron, the experiment was repeated using red cells labelled in vivo with $\mathrm{Fe}^{59}$. During labelling, the $\mathrm{Fe}^{59}$ became incorporated in the haem and therefore the absorption of the label did represent absorption of iron present in the haemoglobin of the swallowed red cells. To avoid the radiation dosage associated with labelling in humans in vivo, rabbits' blood was used, but it is unlikely that this would invalidate the results.

In two experiments the recovery of the $\mathrm{Fe}^{59}$ label in the faeces was $45 \%$ and $73 \%$ after swallowing 10 and $20 \mathrm{ml}$. blood respectively. The marked drop in peroxidase activity in the digestive tract can, therefore, not be explained purely by absorption of iron. The authors found that neither digestion in vitro of blood with proteolytic enzymes (pepsin and trypsin) nor incubation in a faecal suspension resulted in any detectable drop in peroxidase activity. It is of interest that Bramkamp (1929) did show that digestion in vitro of blood with pancreatin reduced the strength of the colour reaction between haemoglobin and benzidine by about $50 \%$.

In the present experiments the quantities of swallowed blood never exceeded $20 \mathrm{ml}$. With a large haemorrhage it is likely that neither digestion nor absorption would be so complete. This might account for the recovery of between $33 \%$ and $85 \%$ of the peroxidase activity by Andrews and Oliver-González (1942) after swallowing between 61 and $65 \mathrm{ml}$. of calves' blood. The site and agent responsible for the deterioration in the peroxidase activity of swallowed haemoglobin is still obscure.

RESULTS FROM CHILDREN Children not on special diets gave numerous false positives with all the tests
(Table II). The results of Needham and Simpson (1952) on adults suggested that 'eating meat seldom accounted for a positive reaction' and 'it was necessary to feed patients with rather large amounts of meat rich in blood (liver and black pudding) before the faeces gave a positive reaction'. It is of interest that these children received no liver or black pudding and usually had one meat meal a day.

It may be that our results were due to immaturity of the digestive tract. Small amounts of meat would then produce faecal peroxidase activity. This is supported by the decrease which occurred when three children, chosen because of their previous positive results, were placed on a meat-free diet (Table II). There was also a tendency for the number of false positives to decrease with increasing age.

Positive occult blood tests on children on a normal diet appear to be of little diagnostic value.

RESULTS FROM NORMAL INFANTS The mothers of the babies in our series were advised to begin mixed feeding when the infants were about 3 months old. In order to attempt a rough division of the purely milkfed babies from the babies on mixed feeds, Table III has been subdivided into those below and above this age. The benzidine tube, perborate, and $0.4 \%$ Moss orthotolidine tests showed some increase in the number of false positives when mixed feeding was begun. The presence of some positive occult blood reactions with the milk-fed babies might be explained by their having begun mixed feeding at an earlier age.

ASSESSMENT OF INDIVIDUAL PAPER TECHNIQUES Because of the numerous false positives obtained with children and babies the individual paper techniques were assessed on the results obtained on adults only (Tables I and IV). The small number of specimens obtained from normal adults on a meat-free diet was unavoidable.

The ideal test for occult blood would be sensitive, give a clear-cut result with no false positives, and be unaffected by diet. It was thought unlikely that any single test would fulfil all these criteria, and that two tests might be required, namely, an insensitive screening test unaffected by diet and a sensitive test requiring dietary preparation. However, Table IV suggests that all the tests which did not give frequent false positives with adults had approximately the same sensitivity. The exception to this was the $1 \%$ benzidine which appeared less sensitive. The value of the apparently sensitive tests, i.e., Hematest, Occultest, $4 \%$ and $2 \%$ Moss orthotolidine tests is doubtful since they gave numerous false positives on normal adults even on a meat-free diet (Table I).

Hematest No mention of dietary restriction was given in the manufacturers' instructions. It was of 
interest that $58 \%$ of specimens from normal adults on a normal diet gave a positive result. Even on the meat-free diet $35 \%$ of specimens were positive. The manufacturers did not give precise instructions about the interpretation of the results. The appearance of a blue colour on the paper, even if localized to the vicinity of the tablet, was interpreted as a positive. Any attempt to interpret only diffuse coloration as positive was difficult because of the numerous borderline results.

These results threw some doubt on the diagnostic value of this test.

Occultest This test is recommended by the manufacturers for detection of blood in urine. However, Cullis (1959) compared the Hematest, Occultest, and Gregersen paper benzidine test on faeces. He found that the Occultest read at 95 seconds gave an $88 \%$ agreement with the Gregersen test.

In our series $88 \%$ of specimens obtained from normal adults on a normal diet and $65 \%$ of specimens obtained from normal adults on a meat-free diet gave positive results when read at two minutes.

A random sample showed no discrepancy between results read at both 95 and 120 seconds. This test did not appear suitable for use with faeces.

Perborate test Fourteen per cent of specimens from normal adults on a normal diet gave a positive result. No positive results were obtained in dieted adults. Consistent positive results were obtained with concentrations of red cell residues above $3.4 \mathrm{ml}$. per $100 \mathrm{~g}$. faeces. This appeared to be a satisfactory paper test.
Moss orthotolidine test The $4 \%$ and $2 \%$ orthotolidine solutions gave a high percentage of false positives. In contrast the $1 \%$ and $0.4 \%$ orthotolidine solutions gave few false positive results. Tests using these concentrations appeared to be satisfactory.

Guaiac test Although very few false positives were produced, the test was difficult to read and it therefore cannot be recommended.

We should like to acknowledge the advice given by Mr. N. Veall on work with isotopes. We should also like to thank Dr. T. V. Mendelsohn, the matron and nursing staff of Ladywell Nursery, and Miss L. Coombe, superintendent health visitor, Guy's Hospital, for kindly arranging for the collection of specimens, and Mrs. $M$. MacDonald for cleaning the large quantity of glassware used. We thank Dr. E. N. Allott, Dr. H. Lehmann, and Dr. W. H. H. Merivale for their interest throughout this investigation.

\section{REFERENCES}

Abbott, C. (1959). Personal communication.

Andrews, J. S., and Oliver-González, J. (1942). J. Lab. clin. Med., 27 1212.

Baker, R. K. (1953). Cancer Res., 13, 137.

Bramkamp, R. G. (1929). J. Lab. clin. Med., 14, 1087.

Cullis, J. E. (1959). J. clin. Path., 12, 486.

Gray, S. J., and Sterling, K. (1950). J. clin. Invest., 29, 1604.

Jones, N. C. Hughes. (1958). Brit. med. J., 1, 493.

Morgan, T. E., and Roantree, R. J. (1957). J. Amer. med. Ass., 164, 1664.

Moss, D. G. (1955). J. med. Lab. Technol., 13, 22.

Needham, C. D., and Simpson, R. G. (1952). Quart. J. Med., 21, 123. Varley, H. (1958). Practical Clinical Biochemistry, 2nd ed. Heinemann, London.

Veall, N., and Vetter, H. (1958). Radioisotope Techniques in Clinical Research and Diagnosis. Butterworth, London. 